\title{
MENGEMBANGKAN KECERDASAN INTERPERSONAL MELALUI METODE BERMAIN PERAN PADA ANAK USIA DINI DI RA AL HIDAYAH BANDUNG
}

\author{
Farida Juniarti ${ }^{1}$, Dedah Jumiatin ${ }^{2}$ \\ ${ }^{1}$ IKIP SILIWANGI, Jl. Ters. Jendral Sudirman Cimahi \\ ${ }^{2}$ IKIP SILIWANGI, Jl. Ters. Jendral Sudirman Cimahi \\ ${ }^{1}$ faresoetopo@gmail.com ${ }^{2}$ dedahcimahi@gmail.com
}

\begin{abstract}
Interpersonal intelligence, also known as social ability, is part of multiple intelligences. Compound intelligence is a potential that has existed since the age of o months. This potential genetic potential of both parents is hereditary. Such intelligence will be increasingly apparent if stimulated, trained and developed. Interpersonal intelligence is very important because it relates to the level of socialization, and greatly influences life in the future, when living and socializing in the community. Because the indicators of having interpersonal intelligence, among others, have good social communication, have thoughts about the people around them, and have the sensitivity to respond to the circumstances around them. Judging from the importance of individuals to have interpersonal intelligence, it would be good to develop early. Early childhood, are individuals in the age group 0-6, who have a potential period to receive various learning experiences from various senses and sensory in their body. The development of children's abilities will be more directed, planned with various methods of applying learning in PAUD institutions. An effective learning approach to developing interpersonal intelligence is by the role playing method. The role playing method is a method that invites children to want to establish relationships with other people, do activities simultaneously, listen and express language, so as to form communicative and friendly characters. The character is an indicator part of interpersonal intelligence.
\end{abstract}

Keywords: intelligence, interpersonal intelligence, role playing method

\begin{abstract}
Abstrak
Kecerdasan interpersonal, dikenal juga kemampuan secara sosial, merupakan bagian dari kecerdasan ganda. Kecerdasan majemuk merupakan potensi yang telah ada sejak usia o bulan. Potensi tersebut potensi genetik dari kedua orangtuanya bersifat hereditas. Kecerdasan tersebut akan semakin nampak jika di rangsang, dilatih dan dikembangkan. Kecerdasan interpersonal sangatlah penting karena berhubungan dengan tingkat sosialisasi, dan sangat mempengaruhi kehidupan di masa yang akan datang, saat hidup dan bersosialisasi di lingkungan masyarakat. Karena indikator dari mempunyai interpersonal intelligence antara lain, mempunyai komunikasi sosial yang baik, mempunyai pemikiran akan diri orang disekitarnya, dan mempunyai sensitifitas untuk merespon keadaan disekelilingnya. Dilihat dari pentingnya individu untuk mempunyai kecerdasan interpersonal, maka alangkah baiknya dikembangkan sejak dini. Anak usia dini, adalah individu dengan kategori usia 0-6, yang mempunyai masa potensial untuk menerima berbagai pengalaman pembelajaran dari berbagai panca indra dan sensori pada tubuhnya. Pengembangan kemampuan anak akan lebih
\end{abstract}




\section{JURNAL CERIA}

ISSN : 2614-6347 (Print) 2614-4107 (Online)

Vol.1 1 No.5 1 September 2018

terarah, terencana dengan berbagai metode penerapan pembelajaran di lembaga PAUD. Pendekatan pembelajaran yang efektif untuk mengembangkan kecerdasan interpersonal ini adalah dengan metode bermain peran. Metode bermain peran, merupakan metode yang mengajak anak untuk mau menjalin hubungan dengan orang lain, melakukan kegiatan bersamaan, menyimak dan mengungkapkan bahasa, sehingga membentuk karakter komunikatif dan bersahabat. Karakter tersebut bagian indikator dari kecerdasan interpersonal.

Kata Kunci: kecerdasan, kecerdasan interpersonal, bermain peran

\section{PENDAHULUAN}

Kecerdasan interpersonal dikenal juga dengan kecerdasan sosial. Kecerdasan interpersonal atau kecerdasan sosial adalah kemampuan dalam bersosialisasi, dan adalah bagian dari multiple intelligence.Kecerdasan ini termasuk kecerdasan majemuk, yang merupakan dasar bagi kehidupan sosial.Indikator kecerdasan ini, pada individu antara lain, kemampuan untuk memahami pendapat dan mengamati pemikiran orang lain dilingkungannya, kemampuan untuk berkomunikasi dengan baik, menjadikan mampu untuk menjalin kontak dan mengukuhkannya dalam waktu lama, dan kemampuan sensitifitas untuk merespon individu lainnya dengan bentuk empati. Individu dengan karakter sosialisasi yang baik mampu memotivasi dirinya dan diri lainnya, sehingga pada umumnya merupakan individu individu yang berhasil dalam kehidupan selanjutnya dilingkungan masyarakat.

Agar individu mempunyai kecerdasan interpersonal, maka diperlukan proses, dan membutuhkan waktu.Untuk itu kecerdasan interpersonal itu dirangsang sejak dini, dilatih dan dikembangkan.

Anak usia dini, merupakan individu dengan kategori usia anak $0-6$ tahun. Masa- masa ini diketahui sebagai masa paling berpotensi bagi seorang anak, masa dimana anak begitu cepat menyerap informasi, menyerap pembelajaran dan pengalaman dari sensori dan berbagai panca indra yang dimilikinya. Anak sedari lahir perlu mendapat rangsangan sejak dalam rahim, karena anak sudah mampu menerima stimulus yang diberikan ibunya.
Kecerdasan interpersonal harus dirangsang pada anak dengan usia 0 -6 tahun, karena di saat ini, dimana terjadi pada anak-anak, yang lebih nyaman berada sendiri, tidak mau bersosialisasi. Indikator berkurangnya kualitas kecerdasan interpersonal pada anak umur tersebut, terlihat dari sifat dan karakternya saat ini, yang terlihat lebih pasif, susah berhubungan dengan teman seusianya, bahkan mempunyai ketakutan tersendiri saat ditinggalkan dalam lingkungan baru.

Hal ini, pada umumnya disebabkan oleh kesibukan orang tua yang seharusnya mendampingi, memberi pengalaman untuk menumbuhkan sikap simpati, empati dan komunikatif pada anak. Selain itu orang tua lebih merasa senang jika anak "tenang".Sehingga tanpa disadari, potensi awal yang harusnya terasah menjadi lebih tersembunyi. Hal itu juga membuat anak kehilangan karakteristiknya..

Dari uraian tersebut, dapat terlihat permasalahan kurangnya pengembangan kemampuan bersosialiasai pada anak dibawah usia 7 tahun saat ini. Karena itu rangsangan dari usia dini dapat dilakukan sejak anak berusia 0-6 tahun.

Pendidikan anak usia dini, merupakan upaya untuk melakukan rangsangan, latihan untuk melakukan peningkatan standar aspek perkembangan dasar, yaitu, aspek pengembangan sosial emosional, aspek pengembangan bahasa, aspek pengembangan kognitif dan fisik motorik. Agar lebih terencana dan terarah, maka dibentuklah suatu wadah pendidikan, yaitu PAUD, atau dikenal dengan lembaga PAUD yang bersifat formal, non formal. 


\section{JURNAL CERIA}

ISSN : 2614-6347 (Print) 2614-4107 (Online)

Vol.1 No.5 September 2018

Pada lembaga PAUD, pembelajaran anak usia dini dimulai dari kategori 3 tahun hingga 6 tahun. Pembelajaran yang diberikan berdasarkan pada asas prinsip pembelajaran anak usia dini.

Oleh karenanya, seorang guru PAUD harus mampu memahami karakteristik, asas dan prinsip anak didiknya. Sebagai upaya pemberian rangsangan dan latihan mampu mengembangkan tingkat aspek pengembangan dasar AUD. Selain memahami karakteristik, asas dan prinsip AUD, seorang guru PAUD harus mampu menguasai berbagai strategi, sebagai upaya pendekatan bagi anak usia dini.

Dari uraian sebelumnya, kecerdasan interpersonal harus dirangsang pada individu sejak 0 bulan hingga 6 tahun, melalui rangasan sensori dan pendekatan pembelajaran. Metode bermain peran merupakan salah satu dari pendekatan pembelajaran anak usia dini, yang mampu mengembangkan berbagai aspek dan juga dilakukan dengan bermain.

Metode bermain peran ini, mampu menstimulasi agar anak aktif dalam kegiatan dan mempunyai pengalaman langsung sehingga anak mampu mengamati dan memahami secara langsung, yang membuat pengalaman belajarnya terasa lebih nyata.

Metode bermain peran, merupakan metode yang mengikutsertakan beberapa anak dalam satu kegiatan, sehingga membuat anak harus mau menjalani interaksi dengan teman dikelompoknya.Pendampingan guru dilakukan, anak diminta, dilatih untuk belajar menyimak dan mengungkapkan bahasa.Sehingga anak dirangsang untuk mau membangun komunikasi dengan anak lainnya.

Metode bermain peran karena dilakukan bersamaan, untuk melatih anak mengerti tanggung jawab saat melakukan kerjasama.

Dari deskripsi hal tersebut, terdapat keterhubungan antara pengembangan kecerdasan interpersonal pada anak dengan penerapan bermain peran.

Maka peneliti mengambil judul "Mengembangkan Kecerdasan Interpersonal Melalui Metode Bermain Peran Pada Anak Usia Dini”

\section{KAJIAN TEORI DAN METODE KECERDASAN INTERPERSONAL}

Kecerdasan atau intelegensi merupakan aktifitas mental. Pada Jamaris (2017:122) terdapat kutipan pernyataan Sternberg (1985) yang mengemukakan bahwa kecerdasan atau intelegensi merupakan aktifitas mental yang diarahkan pada kemampuan yang bertujuan untuk melakukan penyesuaian, memilih, dan membentuk lingkungan yang sesuai dengan kehidupan individu.

Gardner (1993:17) pada Sudjiono:2013 menyatakan bahwa kecerdasan adalah dapat menyelesaikan suatu masalah, menciptakan produk yang berharga dalam satu atau beberapa lingkungan budaya masyarakat. Menurut Gardner, kecerdasan harus mengakui bahwa setiap manusia mempunyai kekuatan pemahaman berbeda dan berdiri sendiri dan harus menerima bahwa setiap individu mempunyai kekuatan yang berbeda dan gaya pemahaman yang kontras.

Kecerdasan pada tiap individu berbeda, tergantung dari potensi saat awal dilahirkan. Ada yang mempunyai potensi kecerdasan lebih dari 1 , karena temuan tersebut, maka dikenal sebutan kecerdasan jamak

Howard Gradner pada buku Jamaris (2017:3), menjelaskan tujuh jenis kecerdasan jamak, dan salah satunya adalah kecerdasan interpersonal.

Menurut Safaria (2015:23), teori kecerdasan interpersonal mempunyai tiga dimensi utama, yaitu (a) social insight, dimana anak mempunyai kemampuan memahami dan menemukan problem solving yang efektif di dalam suatu interaksi sosial. Social insight sendiri mempunyai dua fungsi yaitu monitoring dan kontroling pada dirinya sendiri. (b) social sensitivity, yaitu kemampuan anak untuk merasakan, memahami dan mengamati apa yang dilakukan individu lain. (c) social communication, kemampuan dan keterampilan komunikasi sosial untuk menjalin hubungan relasi yang sehat.

Menurut Jamaris (2017: 52) , mengungkapkan perkembangan kecerdasan interpersonal melalui perilaku, dapat ditunjukkan anak dalam melakukan berbagai kegiatan , antara lain: (a) Melakukan kegiatan bersamaan, (b)Mengikuti percakapan sesuai dengan pokok pembicaraan, (c) Menyesuaikan diri dengan situasi baru, (d) Memahami pikiran orang lain, (e) Mengikuti peraturan dan disiplin, (f) Mengikuti berbagai 


\section{JURNAL CERIA}

ISSN : 2614-6347 (Print) 2614-4107 (Online)

Vol.1 1 No.5 September 2018

isyarat, (g) Penerimaan teman sebaya terhadap diri sendiri, (f) Melakukan tanggung jawab.

\section{METODE BERMAIN PERAN}

Menurut Moeslichatoen : 1998, ,metode adalah bagian dari tehnik penyampaian pembelajaran. Metode merupakan cara, yang dalam bekerjanya berfungsi untuk mencapai tujuan kegiatan. Oleh karena itu, dalam pemilihan metode sebagai pendekatan pembelajaran yang akan dipergunakan dalam program kegiatan anak di PAUD, guru perlu mempunyai tujuan yang kuat dan mengacu pada indikator yang mendukung pemilihan metode tersebut seperti karakteristik tujuan.

Bermain memberikan rangsangan bagi sosialisasi anak ketika melakukan aktifitas dengan anak lain dan merupakan sarana yang paling utama bagi pengembangan kemampuan bersosialisasi, dan mengasah rasa empati terhadap orang lain serta mengurangi sikap egosentris. Berfungsi juga sebagai stimultan sosialisasi anak, Indikator anak perilaku prososial seperti menunggu giliran, kerja sama, saling membantu, dan berbagi, dapat diasah melalui bermain

Nama lain dari bermain peran, seni peran, atau bermain simbolis, pura-pura, fantasi,imajinasi,dan main drama, sangat penting untuk pengembanganaspek kognitif, sosial emosional anak usia kelompok A. Bermain peran adalah mengimajinasikan perilaku, watak dalam pengulangan kejadian yang diulang kembali, kejadian di waktu yang akan datang, atau padasaat ini, yang penting atau situasi imajinatif. Anak-anak menjadi tokoh pemeran, berimajinasi untuk menjadi orang lain dengan memahami peran untuk menghayati tokoh yang diperankan, sesuai dengan karakter, dan motivasi yang dibentuk oleh tokoh yang telah ditentukan.

Dari uraian diatas, dapat disimpulkan, bermain peran merupakan pendekatan pembelajaran dimana para pemain yang menjadi tokoh-tokoh imajinasi atau benda-benda sekitar anak sehingga dapat mengembangkan kreatifitas imaijinasi dan penghayatan terhadap kegiatan yang dilaksanakan, dan menjalankan fungsi tokoh yang dipegangnya.

Sedangkan menurut Sudjiono Sudjiono:2010. Bermain Peran adalah kegiatan yang berfokus pada kegiatan dramatisasi, tempat anak bermain untuk memerankan tugas-tugas anggota. Dengan demikian kegiatan bermain peran, dapat di artikan sebagai cara mendramatisasikan berperilaku didalam hubungan sosial.

Dari uraian diatas, terlihat keterhubungan antara penerapan metode bermain peran sebagai satu dari cara untuk pengembangan kecerdasan interpersonal pada anak di lembaga PAUD.

\section{METODE PENELITIAN}

Penelitian kualitatif deskriptif adalah penelitian yang menjawab pertanyaan dengan penjelasan yang lebih berupa pemaparan, narasi, mengenai gejala seperti yang dimaksudkan dalam suatu permasalahan penelitian yang bersangkutan. Selain itu pengertian deskriftif adalah upaya mendeskripsikan kondisi realita di lapangan untuk memperoleh data mengenai objek - objek penelitian. Tujuan penelitian yang diambil berdasarkan permasalahan , yaitu untuk mengembangkan kecerdasan interpersonal melalui metode bermain peran.

Penelitian dilakukan di RA Alhidayah, Jl. Logam (Timah) No. 1 Bandung, pada kelompok A. Kelompok A, merupakan kategori anak dengan usia $4-5$ tahun.

Selama ini, kegiatan bermain peran di kelompok A, RA Al Hidayah ini, jarang dilakukan sebagai pendekatan pembelajaran, mengingat jumlah anak dalam kelas sebanyak 28 orang dengan guru sebanyak 2 orang. Pada umumnya metode bermain peran dilakukan, tetapi tidak dimaksudkan untuk menstimulasi kecerdasan interpersonal dalam penilaian dan evaluasi, tetapi lebih ke arah interaksi komunikasi, dan pemahaman terhadap isi materi.

Saat melakukan penelitian, peneliti mengamati dan mengobservasi kegiatan bermain peran.

Standar Operasional harian kegiatan pembelajaran, dapat diketahui dari Perencanaan pembelajaran setiap harinya. Bermain peran dilaksanakan setelah circle time. Tetapi saat penelitian, dijadikan kegiatan utama karena sistem rolling.

\section{Hasil dan Pembahasan}

Pra pelaksanaan bermain peran, guru melakukan penyamaan pandangan (apersepsi), tentang bermain peran sesuai tema hari itu, dilakukan dengan bercakap - cakap atau tanya jawab. 


\section{JURNAL CERIA}

ISSN : 2614-6347 (Print) 2614-4107 (Online)

Vol.1 1 No.5 September 2018

Kemudian dengan bantuan media audio visual, guru menggunakan media film animasi kartun durasi $2-4$ menit, kemudian setelah itu pemantapan pemahaman melalui dialog dan bercakap -cakap mengenai film tersebut.

Setelah itu, pemilihan peran, bersifat bebas terpimpin, anak yang berminat boleh mengajukan, walaupun pada akhirnya guru yang memutuskan sesuai dengan pemahaman anak terhadap isi naskah.Peran pun kadang diberikan berdasarkan pendapat lainnya.Setelah itu baru dimulai kegiatan bermain peran. Kegiatan bermain peran berjalan berdasarkan contoh yang dilihat pada film dan dibantu dengan naskah dan bimbingan guru.

Saat kegiatan bermain peran, berlangsung terlihat interaksi antar anak dalam sosialisasi dan komunikasi.Selain itu ada interaksi ekspresi dan gerak pada anak sesuai peran yang diberikan, Terlihat anak mendengarkan dengan menyimak bahasa yang diucapkan oleh temannya, dan dapat melihat secara baik hubungan antara berbagai peran yang dimainkan bersama. Dan sebagai upaya guru agar kegiatan bermain peran berjalan dengan baik, guru memberikan penguatan kepada anak yang masih pemalu atau ragu untuk berinteraksi.Maka guru akan membisikkan kalimat yang mudah diucapkan anak, atau memberikan kalimat pertama pada anak untuk membantu anak memulai suatu dialog.

Salah satu manfaat interaksi komunikasi pada anak berkegiatan, yaitu menambah perbendaharaan kosa kata baik yang berasal dari percakapan teman atau tambahan berupa bimbingan kalimat oleh guru.

Setelah kegiatan bermain peran selesai, maka guru memberikan apresiasi kepada para pemeran, dan menanyakan pendapat murid lainnya yang saat itu menonton.Setelah pemberian apresiasi, guru memberikan pemahaman sebagai evaluasi, juga memberikan motivasi, agar anak lainnya mau berpartisipasi dalam bermain peran selanjutnya.

Hal tersebut, dapat menstimulasi rasa percaya diri.Selain itu anak mau untuk lebih bersosialisasi dengan temannya lainnya sehingga memperluas sosialisasi dan meningkatkan kecerdasan interpersonal.

Peningkatan interpersonal intelligence dapat dilihat saat anak mau menerima siapapun yang menjadi partnernya, tidak pemilih dalam berteman.Tanpa ragu mau berinteraksi gerak dan ekspresi serta pengucapan dialog.Dan saling mau bekerjasama sehingga kegiatan bermain perannya berlangsung baik.

Dari hal tersebut, dapat dikatakan metode bermain peran, merupakan metode pembelajaran yang menyenangkan, mengembangkan semua aspek secara bersamaan, serta membentuk karakter meningkatkan kecerdasan interpersonal anak.

Indikator meningkatnya kecerdasan interpersonal anak dapat diidentifikasi melalui adanya perubahan dari perilaku dan interaksi komunikasi.Misal, sebelum bermain peran kadang anak tidak mengenal banyak tentang temannya, setelah bermain peran maka anak mampu menjelaskan identitas temannya, dan diperankan oleh temannya.

Saat anak dalam kegiatan tersebut, mampu mengikuti alur percakapan , dan mampu mengeluarkan ide. Selain itu dapat terlihat jika anak mampu menceritakan pengalaman sesuai dengan tema bermain peran, kemudian mampu memberikan saran dan pendapat tentang kejadian yang sesuai dengan pengalamannya. Kemudian sikap empati terhadap temannya meningkat, dengan mampu mengemukakan tindakan,untuk menolong ataupun memberikan perhatian terhadap orang - orang yang membutuhkan.

Peningkatan kecerdasan interpersonal terlihat pada saat anak mengikuti peraturan, dan jika menolak peraturan, anak dapat mengajukan alasan rasional.

\section{KESIMPULAN}

Anak usia dini, merupakan anak yang harus mendapatkan stimulasi yang baik dan terus menerus sesuai tahapan usia agar mampu mendapatkan pengalaman sebagai pembelajaran dan modalitas untuk kehidupan di masa depan.

Selain aspek perkembangan yang berhubungan dengan Intelligence, Emotional, dan Spiritual quotient, maka pada anak terdapat potensi kecerdasan lainnya, yang dikenal dengan kecerdasan majemuk.

Salah satu kecerdasan ganda, yang dibutuhkan oleh individu sebagai mahluk sosial, yaitu kecerdasan interpersonal.Kecerdasan 


\section{JURNAL CERIA}

ISSN : 2614-6347 (Print) 2614-4107 (Online)

Vol.1 1 No.5 September 2018

interpersonal satu pendukung utama agar seorang individu mampu merespon dengan baik dan berinteraksi dengan individu lainnya. Dan berhubungan dengan semakin banyaknya pengetahuan dan pengalaman yang akan diperoleh selama berinteraksi di dalam masyarakat.

Semakin baik tingkat sosialisasi seorang anak pada usia dini, menunjukkan indikator baik pada kecerdasan interpersonalnya. Dan jika terus menerus mendapatkan stimulasi pada perkembangan kecerdasan interpersonalnya akan mampu membuat anak tersebut menjadi individu yang mempunyai relasi sosial yang luas, mampu memahami keinginan orang lain tanpa perlu berbenturan dengan keinginan sendiri, mampu mempunyai ide, gagasan, konsep dalam mengembangankan sesuatu, membantu sesama dan mampu menjadi pemimpin yang baik.

\section{DAFTAR PUSTAKA}

Jamaris (2017), Pengukuran Kecerdasan Jamak,Bogor: Ghalia Indonesia.2017

R., Moeslichatoen (2004), Metoda Pengajaran di Taman Kanak - Kanak, Rineka Cipta: Jakarta, 2007.

Safaria,

$\mathrm{T}$.

(2005),

InterpersonalIntelligenceMetode

Pengembangan Interpersonal Anak, Yogyakarta: Amara Books

Sudjiono (2010), Bermain Kreatif Berdasarkan Kecerdasan Jamak, Index: Jakarta, 2010.

Sudjiono (2013), Konsep Dasar Pendidikan Anak Usia Dini,Index:Jakarta,2013 